\title{
ANALISIS FAKTOR-FAKTOR YANG MEMPENGARUHI KEDALAMAN JANGKAUAN (DEPTH OF OUTREACH) LEMBAGA KEUANGAN MIKRO (LKM) UED-SP DI KECAMATAN RAMBAH KABUPATEN ROKAN HULU
}

\author{
Ahmad Rifai ${ }^{(2),}$ Siswanto $^{(1)}$, Eri Sayamar ${ }^{(2)}$ \\ (1) Mahasiswa Jurusan Agribisnis Fakultas Pertanian Universitas Riau, Pekanbaru \\ (2) Staf Pengajar Jurusan Agribisnis Fakultas Pertanian Universitas Riau, Pekanbaru \\ Program Studi Agribisnis, Jurusan Agribisnis \\ Fakultas Pertanian, Universitas Riau, Kode Pos 28293, Pekanbaru \\ e-mail: Siswanto_z@yahoo.com
}

\begin{abstract}
This study analysis the factors affecting the depth of outreach of Microfinance Institutions (MFIs) of UED-SP at Rambah Sub-district Rokan Hulu District. Factors thought to influence the depth of outreach is age of UED-SP, ROA, percent of trading sector clients, percent of agriculture sector clients and number of woman clients. The sampling method is done using by purposive sampling. This study obtained a sample of twelve UED-SPs in the village at Rambah District from in the period of 2012-2015. The data used is secondary data form pooled data. Data were obtained based on the financial reports of each of the samples. This study uses quantitative approach with analysis technique used is multiple linear regression analysis with fixed effect model of pooled data that were previously tested with the classical assumption test. Hypothesis testing using $t$-statistic and the F-statistic with 95\% confidence level. Based on the classic assumption test found no variables that deviate. This shows that the available data has been qualified using the linear regression equation model. The results of this study show that depth of outreach are statistically significant infiuenced by age of UED-SP. However, it's negatively affect on depth of outhreach. Whereas ROA, number of woman borrower, percent of agriculture sector clients and percent of trading sector clients has no affect on depth of outhreach. Predictive ability of these five variables on the depth of outhreach is 77,66 percent, while the 22,34 percent influenced by other factors not included in the research model.
\end{abstract}

Keywords : microfinance institutions, depth of outreach, microentrepreneurs, fixed effect model of pooled data

\begin{abstract}
Abstrak : Penelitian ini bertujuan untuk menguji faktor-faktor yang mempengaruhi kedalaman jangkauan (Depth of Outrech) pada LKM UED-SP di Kecamatan Rambah Kabupaten Rokan Hulu. Faktor-faktor yang diduga berpengaruh terhadap kedalaman jangkauan adalah umur UED-SP, rasio pengembalian aset (ROA), jumlah peminjam wanita, proporsi peminjam sektor pertanian dan proporsi peminjam sektor perdagangan. Metode pengambilan sampel dilakukan dengan menggunakan purposive sampling. Dalam penelitian ini diperoleh sampel sebanyak 12 LKM UED-SP di Desa/Kelurahan yang ada di Kecamatan Rambah dan data yang dihimpun adalah 4 tahun dari tahun 2012-2015. Data yang digunakan adalah data sekunder data panel. Data diperoleh berdasarkan laporan keuangan dari masing-masing sampel. Teknik analisis yang digunakan adalah analisis regresi linear berganda data panel dengan model Fixed Effect (FEM) yang sebelumnya diuji dengan uji asumsi klasik. Uji hipotesis menggunakan t-statistik serta F-statistik dengan tingkat kepercayaan 95\%. Berdasarkan uji asumsi klasik tidak ditemukan variabel yang menyimpang. Hal ini menunjukkan bahwa data yang tersedia telah memenuhi syarat menggunakan model
\end{abstract}


persamaan linear berganda. Hasil penelitian menunjukkan bahwa variabel umur UEDSP berpengaruh signifikan terhadap kedalaman jangkauan. Namun berpengaruh negatif terhadap kedalaman jangkauan. Kemampuan prediksi kelima variabel tersebut terhadap kedalaman jangkauan adalah 77,66 persen, sedangakan 22,34 persen dipengaruhi oleh faktor lain yang tidak dimasukkan ke dalam model penelitian.

Kata kunci : lembaga keuangan mikro, kedalaman jangkauan, model efek tetap (FEM) data data panel

\section{PENDAHULUAN}

Kemiskinan yang terjadi di Indonesia, khususnya di Kabupaten Rokan Hulu Provinsi Riau menjadi masalah yang sangat sulit untuk diselesaikan. Sehingga pemecahannya harus komprehensif dengan terlebih dahulu mencari akar permasalahannya. Kabupaten Rokan Hulu adalah salah satu kabupaten di Provinsi Riau yang memiliki tingkat kemiskinan yang tinggi. Hal tersebut dapat dilihat pada data kemiskinan di Provinsi Riau tahun 2010 sampai tahun 2015. Pada tahun 2010 angka kemiskinan di Kabupaten Rokan Hulu berada pada angka 62,40 ribu atau sebesar13,03 persen. Sedangkan pada tahun 2015 persentase jumlah masyarakat miskin di Kabupaten Rokan Hulu menurun menjadi 11,05 persen namun jumlahnya meningkat menjadi 64,74 ribu (BPS Provinsi Riau).

Program Pemberdayaan Desa/Kelurahan (PPD) adalah salah satu program penanggulangan kemiskinan sebagai upaya percepatan penyelesaian rendahnya kesejahteraan masyarakat yang merupakan kewajiban pemerintah. Lembaga Keuangan Mikro Usaha Ekonomi Desa Simpan Pinjam (LKM UED-SP) merupakan salah satu implementasi dari Program Pemberdayaan Desa (PPD) Provinsi Riau, khususnya di Kabupaten Rokan Hulu. Tujuan utamanya adalah sebagai fungsi sosial penanggulangan kemiskinan, dengan cara memberikan akses khusus pemberian kredit kepada masyarakat miskin. Peran ini dapat dijalankan usaha mikro dengan beberapa prasyarat, diantaranya adalah ketersediaan dan akses pendanaan untuk memulai usaha atau untuk memperluas aktivitas usaha.

Lembaga Keuangan Mikro (LKM) UEDSP memiliki karakteristik khusus yakni memberikan kredit kepada usaha mikro/kecil dan masyarakat miskin. Oleh karena itu, dalam menilai kinerja suatu lembaga keuangan mikro harus memperhatikan ukuran jangkauannya (outreach). Jangkauan (outreach) merupakan kemampuan LKM dalam memberikan pelayanan jasa keuangan yang mengacu pada jumlah nasabah yang dilayani. Jangkauan tersebut dibedakan menjadi dua yaitu kedalaman jangkauan (depth of outreach) dan keluasan jangkauan (breadth of outreach). Dengan pertumbuhan yang cepat dari kredit mikro, luasnya jangkauan juga meningkat baik di tingkat industri dan juga di tingkat individu LKM. Namun, suatu lembaga keuangan mikro yang lebih memperhatikan luas jangkauan cenderung sulit untuk memiliki perhatian yang sama dengan kedalaman jangkauannya, karena keduanya membutuhkan sumber daya yang besar (Handayani, 2013). Akibatnya, kedalaman jangkauan menerima perhatian lebih dari semua pihak yang peduli tentang penjangkauan sosial keuangan mikro secara keseluruhan, termasuk pembuat kebijakan.

Keterbatasan dalam mengukur kedalaman jangkauan adalah tidak adanya informasi pendapatan guna mengukur tingkat kemiskinan peminjam. Karena data kekayaan peminjam tidak dikumpulkan sehingga data pendapatan/kekayaan tidak tersedia bagi peneliti. Oleh karena itu ukuran yang paling banyak digunakan adalah rata-rata jumlah pinjaman perpeminjam (Average Outstanding Loans/AOL). Berdasarkan informasi Pengelola LKM UED-SP, syarat besarnya kredit yang diminta adalah sesuai dengan kemampuan peminjam dalam mengembalikan kredit. Sehingga diduga terdapat korelasi yang kuat antara rata-rata jumlah pinjaman dengan ratarata jumlah pendapatan karena jumlah pendapatan merupakan indikator dalam mengukur kemiskinan. Quayes (2012) mengungkapkan, meskipun tidak ada ukuran yang sempurna dari tingkat kemiskinan, itu sangat baik dalam mengukur kedalaman jangkauan karena adanya korelasi positif yang kuat antara tingkat pendapatan dan ukuran 
pinjaman. Dalam kata lain, peminjam miskin akan lebih kecil ukuran pinjamannya.

Peminjam dari sektor pertanian merupakan salah satu indikator dalam menilai kedalaman jangkauan LKM, karena usaha sektor pertanian umumnya dikelola oleh masyarakat pedesaan yang miskin. Namun, kondisi di Kecamatan Rambah menunjukkan bahwa petani didominasi oleh subsektor perkebunan sehingga sangat jarang ditemui petani yang tergolong miskin. berdasarkan data rata-rata pinjaman, UED-SP yang memiliki rata-rata pinjaman tinggi didominasi oleh UEDSP yang memiliki peminjam sektor peminjam pertanian yang dominan. Sebagai contoh adalah LKM UED-SP di Desa Rambah Tengah Barat yang memiliki rata-rata pinjaman 10 juta rupiah dengan proporsi peminjam pertanian diatas 50 persen. Berdasarkan teori-teori kedalaman jangkauan dalam penelitian serupa yang dilakukan sebelumnya serta disesuaikan dengan data dan kondisi objek penelitian variabel umur (AGE), ROA, proporsi peminjam sektor perdagangan (DAGANG), proporsi peminjam sektor pertanian (TANI) dan jumlah peminjam wanita (WANITA) diduga berpengaruh terhadap rata-rata jumlah pinjaman (AOL) yang digunakan sebagai proksi kedalaman jangkauan.

Penelitian ini bertujuan untuk mengidentifikasi kinerja jangkauan LKM UEDSP di Kecamatan Rambah Kabupaten Rokan Hulu dan menganalisis faktor-faktor yang mempengaruhi kedalaman jangkauan (depth of outreach) Lembaga Keuangan Mikro (LKM) UED-SP di Kecamatan Rambah Kabupaten Rokan Hulu.

\section{METODOGI PENELITIAN}

\section{Lokasi dan Waktu Penelitian}

Penelitian ini dilaksanakan pada Lembaga Keuangan Mikro (LKM) Usaha Ekonomi DesaSimpan Pinjam (UED-SP) Kecamatan Rambah Kabupaten Rokan Hulu Provinsi Riau. Waktu penelitian dimulai pada bulan Oktober 2016 Mei 2017.

\section{Data dan Analisis Data}

Metode pengambilan sampel dilakukan dengan menggunakan purposive sampling. Data dihimpun selama 4 tahun (2012-2015) pada
LKM UED-SP di Desa/Kelurahan yang ada di Kecamatan Rambah Kabupaten Rokan Hulu.

Data yang digunakan adalah data sekunder yaitu laporan keuangan tahunannya. Menurut Ghozali (2015), Data runtun waktu (time-series) didasarkan pada observasi yang dilakukan pada waktu berbeda, Data antar ruang (cross-sectional) adalah data yang dikumpulkan pada satu waktu tertentu sedangkan data panel (Pooled data) adalah yang memiliki gabungan dua elemen yaitu runtun waktu (time-series) dan antar ruang (cross-sectional).

Metode analisis yang digunakan adalah statistik deskriptif yang digunakan untuk mengidentifikasi kinerja jangkauan LKM UEDSP yang disesuaikan dengan variabel-variabel yang digunakan pada penelitian ini. Selain itu, untuk analisis faktor-faktor yang mempengaruhi kedalaman jangkauan (depth of outreach) LKM UED-SP di Kecamatan Rambah Kabupaten Rokan Hulu menggunakan alat analisis regresi linear berganda data panel dengan metode Fixed Effect (FEM) yang sebelumnya diuji dengan uji asumsi klasik. Analisis regresi data panel menggunakan alat bantu program E-views

Analisis data menggunakan model Regresi Panel menggunakan uji chow untuk memilih antara model Pooled Least Square (PLS) dan Fixed Effect Model (FEM). Jika yang dipilih adalah model FEM maka dilakukan uji lanjutan, yakni uji haussman. Uji haussman digunakan untuk memilih model antara Fixed Effect Model dan Random Effect Model. didapatkan salah satu model dari uji tersebut, kemudian dilakukan pengujian asumsi klasik. Dalam penelitian ini digunakan uji Normalitas dan uji Multikolinearitas, kemudian dari model yang terbentuk dapat diketahui seberapa besar pengaruh perubahan variabel bebas terhadap variabel terikat.

\section{Model Penelitian}

Model dasar penelitian ini didasarkan pada spesifikasi model yang pernah digunakan oleh Olivares-Polanco (2005), modifikasi model sebagai berikut:

$$
\begin{array}{ll}
\text { AOLit }= & \alpha+\beta 1 \text { AGEit }+\beta 2 \text { ROAit }+\beta 3 \\
& \text { DAGANGit }+\beta 4 \text { TANIit }+\beta 5 \\
& \text { WANITAit }+ \text { cit..(1) } \\
\text { Keterangan : } & \\
\alpha & : \text { Konstanta } \\
\beta & : \text { Koefisien masing - masing variabel }
\end{array}
$$


AOL : Rata-rata besarnya kredit untuk setiap nasabah kredit. Makin kecil AOL dianggap semakin meningkatkan kedalam jangkauan (depth of outreach).

AGE : Umur UED-SP, diukur dari mulai beroperasi tahun 2005 sampai akhir tahun penelitian $(2012,2013,2014$, 2015).

ROA : Rasio antara besarnya laba bersih terhadap nilai aset.

DAGANG : Proporsi peminjam sektor perdagangan

TANI : Proporsi peminjam sektor pertanian

WANITA : Jumlah peminjam wanita.

\section{Pemilihan Model Regresi Data Panel a. Uji Chow}

Uji chow digunakan untuk memilih salah satu model pada regresi data panel, yaitu antara model efek tetap (fixed effect model) dengan model koefisien tetap (common effect model)/Pooled Least Square. Prosedur pengujian sesuai dengan model regresi pada persamaan (1) sebagai berikut:

Hipotesis:

$\mathrm{H}_{0}=\alpha_{1}=\alpha_{2}=\ldots=\alpha_{12}=0$ (efek unit cross section secara keseluruhan tidak berarti)

$\mathrm{H}_{1}=$ Minimal ada satu $\alpha i \neq 0 ; i=1,2, \ldots, 12$ (efek wilayah berarti)

Jika nilai F-hitung > F-tabel maka $\mathrm{H}_{0}$ ditolak, artinya model panel yang baik untuk digunakan adalah Fixed Effect Model, dan sebaliknya. Jika $\mathrm{H}_{0}$ diterima, berarti model Pooled Least Square yang dipakai dan dianalisis.

\section{b. Uji Haussman}

Uji Haussman digunakan untuk memilih antara Fixed Effect Model (FEM) dan Random Efect Model (REM). Pengambilan keputusan ditentukan dengan perbandingan nilai Uji Haussman dengan nilai Chi-Square tabel. Nilai Chi-Square dengan degree of freedom dan menggunakan nilai signifikansi 5 persen. Jika nilai Uji Haussman lebih besar dari nilai ChiSquare tabel, maka model yang digunakan adalah Fixed Effect, artinya $\mathrm{H}_{0}$ diterima. Apabila nilai Uji Haussman lebih kecil dari nilai Chi-Square tabel maka yang digunakan adalah Random Effect, artinya $\mathrm{H}_{0}$ ditolak.

\section{Goodness of fit model}

Ketepatan fungsi regresi sampel dalam menaksir nilai aktual dapat diukur dari goodness of fit. Secara statistik dapat diukur dari nilai koefisien determinasi, nilai statistik F dan nilai statistik t. Perhitungan statistik disebut signifikan secara statistik apabila nilai uji statistiknya berada dalam daerah kritis (daerah dimana $\mathrm{H}_{0}$ ditolak). Sebaliknya disebut tidak signifikan bila nilai uii statistiknya berada dalam daerah dimana $\mathrm{H}_{0}$ tidak dapat ditolak (Ghozali, 2015).

\section{a. Koefisien Determinasi $\left(\mathbf{R}^{2}\right)$}

Koefisien determinasi $\mathrm{R}^{2}$ digunakan untuk menyatakan tingkat keeratan hubungan antara variabel-variabel independen dan variabelvariabel dependen. Nilai $\mathrm{R}^{2}$ digunakan untuk melihat seberapa besar kemampuan variabel independen yang digunakan dalam persamaan dapat menjelaskan variabel dependen. Nilai $\mathrm{R}^{2}$ terletak di antara 0 dan 1 . Semakin besar nilai $\mathrm{R}^{2}$ (mendekati 1), dapat disimpulkan bahwa model regresi yang digunakan adalah baik.

\section{b. Uji Signifikan Simultan (Uji F-statistik)}

Uji F-statistik digunakan untuk mengetahui apakah variabel-variabel independen yang digunakan dalam model secara bersama-sama berpengaruh terhadap variabel dependen. Uji F dilakukan dengan membandingkan nilai Fstatistik terhadap nilai F-tabel. Jika F-hitung > F-tabel yaitu $\mathrm{F} \alpha(k-1, n-k)$ maka hipotesis nol ditolak. Dimana F $\alpha(k-1, n-k)$ adalah nilai kritis $F$ pada tingkat signifikansi $\alpha$ dan derajad bebas (df) pembilang $(k-1)$ serta derajad bebas (df) penyebut ( $n-\mathrm{k}$ ) (Ghozali, 2015).

\section{c.Uji Signifikasi Individual (Uji t-statistik)}

Uji t-statistik digunakan untuk menguji secara individu apakah suatu variabel independen berpengaruh signifikan terhadap variabel dependen. Metode yang digunakan dalam $t$-test adalah dengan cara membandingkan nilai thitung dari masing-masing koefisien variabel bebas terhadap nilai t-tabel pada derajat keyakinan 1 persen, 5 persen,atau 10 persen. Jika t-hitung > t-tabel berarti variabel independen berpengaruh signifikan terhadap variabel dependen. Semakin kecil derajat keyakinan yang digunakan, maka kemungkinan penolakan HO semakin kecil, sehingga dapat disimpulkan variabel independen tersebut berpengaruh signifikan terhadap variabel dependen (Ghozali, 2015). 
Ahmad Rifai, Siswanto, Eri S. : Analisis Faktor-Faktor yang Mempengaruhi ...

Tabel 1. Gambaran umum LKM UED-SP di Kecamatan Rambah

\begin{tabular}{clcccrc}
\hline No & \multicolumn{1}{c}{ UED-SP } & $\begin{array}{c}\text { Tahun } \\
\text { Berdiri }\end{array}$ & $\begin{array}{c}\text { Usia } \\
\text { (Tahun) }\end{array}$ & $\begin{array}{c}\text { Modal Awal } \\
\text { (Rupiah) }\end{array}$ & \multicolumn{2}{c}{$\begin{array}{c}\text { Perguliran Jumlah } \\
\text { Peminjam (Orang) } \\
2012\end{array}$} \\
\hline 1 & Babussalam & 2006 & 9 & 410.000 .000 & 597 & 798 \\
2 & Pematang Berangan & 2006 & 9 & 410.000 .000 & 451 & 685 \\
3 & Tanjung Belit & 2007 & 8 & 500.000 .000 & 240 & 435 \\
4 & Pasir Baru & 2007 & 8 & 430.000 .000 & 311 & 394 \\
5 & Sialang Jaya & 2007 & 8 & 500.000 .000 & 167 & 220 \\
6 & Koto Tinggi & 2007 & 8 & 430.000 .000 & 284 & 411 \\
7 & Rambah Tengah Barat & 2009 & 6 & 500.000 .000 & 154 & 220 \\
8 & Rambah Tengah Hilir & 2010 & 5 & 405.000 .000 & 89 & 245 \\
9 & Suka Maju Rambah & 2010 & 5 & 500.000 .000 & 154 & 316 \\
10 & Pasir Maju & 2011 & 4 & 400.000 .000 & 88 & 227 \\
11 & Rambah Tengah Utara & 2008 & 7 & 420.000 .000 & 154 & 168 \\
12 & Pasir Pengaraian & 2007 & 8 & 500.000 .000 & 288 & 411 \\
\hline
\end{tabular}

Sumber: Laporan keuangan LKM UED-SP Kecamatan Rambah 2012-2015 (Diolah)

\section{HASIL DAN PEMBAHASAN}

\section{Gambaran Umum LKM UED-SP di Kecamatan Rambah}

Gambaran umum UED-SP di Kecamatan

Rambah ditampilkan pada Tabel 1. Berdasarkan

Tabel 1 menunjukkan bahwa Babussalam dan

Pematang Berangan merupakan desa pertama yang mengoperasikan UED-SP yang berdiri pada tahun 2006, kemudian diikuti oleh 10 desa lainnya. Sehingga jika dilihat dari banyaknya jumlah peminjam atau keluasan jangkauan, UED-SP di desa tersebut lebih luas jangkauannya dibandingkan UED-SP pada desa lain. LKM UED-SP Desa Pematang Berangan merupakan desa yang memiliki rata-rata jumlah peminjam terbanyak, yaitu dengan nilai 87 orang per tahun. Sedangkan desa yang memiliki rata-rata jumlah pinjaman terendah terdapat pada UED-SP di Desa Rambah Tengah Utara, yaitu sebesar 24 orang per tahun. LKM UEDSP Desa Pasir Maju merupakan UED-SP termuda yang baru berdiri selama 4 tahun, namun UED-SP tersebut mengalami pertumbuhan yang lebih baik jika dibandingkan dengan beberapa desa lain yang lebih tua, yaitu sebesar 57 orang per tahun.

Penyebab meningkatnya jumlah peminjam UED-SP di Kecamatan Rambah adalah karena kemudahan akses nasabah dalam meminta kredit dengan tingkat kepercayaan masyarakat yang tinggi terhadap LKM tersebut. Semakin tinggi tingkat kepercayaan masyarakat terhadap LKM UED-SP, maka semakin terjaga keberlanjutan LKM karena uang yang ada terus bergulir kepada masyarakat, sehingga tidak habis hanya untuk biaya operasional saja. Seiring peningkatan jumlah peminjam, LKM UED-SP tentunya harus tetap fokus pada tujuan program sebagai upaya pemberdayaan masyarakat. Karena sesuai teori kedalaman jangkauan, semakin meningkat jumlah peminjam dikhawatirkan akan semakin dangkal kedalaman jangkauannya jika sumberdaya yang dimiliki tidak mencukupi. Semakin banyak peminjam yang dilayani akan semakin mengurangi fokus LKM UED-SP terhadap peminjam paling miskin sebagai objek pemberdayaan. Namun, jika program tersebut tetap konsisten dan lebih adil (distribusi kredit merata) dalam melayani peminjam, maka kedalaman jangkauan tetap terjaga. Sehingga, aktifitas ekonomi masyarakat akan semakin meningkat, seperti timbulnya usaha-usaha dan terciptanya lapangan kerja baru. Sehingga tujuan pemberdayaan masyarakat dapat terwujud.

Dana LKM UED-SP berasal dari dana sharring pemerintah kabupaten/kota kepada desa/kelurahan. Sebagaimana tertuang dalam Surat Keputusan Menteri Dalam Negeri Republik Indonesia Nomor 140/640/SK tentang Pedoman Alokasi Dana sharring dari 
Ahmad Rifai, Siswanto, Eri S. : Analisis Faktor-Faktor yang Mempengaruhi ...

Tabel 2. Pertumbuhan dari rata-rata jumlah pinjaman per peminjam pada LKM UED-SP di Kecamatan Rambah tahun 2012-2015

\begin{tabular}{llrrr}
\hline \multirow{2}{*}{ No } & \multicolumn{1}{c}{ UED-SP } & \multicolumn{2}{c}{ Rata-rata Jumlah Pinjaman $(\mathrm{Rp})$} & \multicolumn{2}{c}{$\begin{array}{c}\text { Pertumbuhan } \\
\text { Rata-rata }(\%)\end{array}$} \\
\cline { 3 - 4 } & & \multicolumn{1}{c}{2012} & \multicolumn{1}{c}{$6.940 .914,79$} & 10,52 \\
\hline 1 & Babussalam & $5.275 .544,39$ & $6.615 .620,44$ & $-0,53$ \\
2 & Pematang Berangan & $6.723 .281,60$ & $9.380 .883,68$ & 3,15 \\
3 & Tanjung Belit & $8.570 .101,67$ & $6.949 .611,68$ & $-0,03$ \\
4 & Pasir Baru & $6.954 .983,92$ & $9.476 .004,55$ & 0,69 \\
5 & Sialang Jaya & $9.284 .431,14$ & $7.859 .464,72$ & 2,52 \\
6 & Koto Tinggi & $7.307 .570,42$ & $10.518 .127,20$ & 17,41 \\
7 & Rambah Tengah Barat & $6.909 .090,91$ & $8.091 .836,73$ & 69,70 \\
8 & Rambah Tengah Hilir & $2.617 .977,53$ & $9.924 .177,22$ & 21,15 \\
9 & Suka Maju Rambah & $6.071 .428,57$ & $9.310 .572,69$ & 44,81 \\
10 & Pasir Maju & $3.971 .590,91$ & $10.089 .820,30$ & $-0,47$ \\
11 & Rambah Tengah Utara & $10.233 .766,20$ & $7.765 .898,30$ & 2,68 \\
12 & Pasir Pengaraian & $7.187 .500,00$ & $102.922 .932,30$ & 8,97 \\
\hline Jumlah & $81.107 .267,26$ & \\
\hline
\end{tabular}

Sumber: Laporan keuangan LKM UED-SP Kecamatan Rambah 2012-2015 (Diolah)

pemerintah kabupaten/kota kepada desa/kelurahan tanggal 22 Maret 2005. Bantuan dana yang dikucurkan oleh pemerintah ialah sebanyak Rp.500.000.000 kepada setiap Usaha Ekonomi Desa/Kelurahan Simpan Pinjam (UED-SP) sebagaimana diamanatkan dalam Peraturan Gubernur Riau Nomor 15 Tahun 2006. Akan tetapi realisasi yang terjadi dilapangan berbeda-beda untuk setiap LKM UED-SP. Seperti pada UED-SP Desa Pasir Maju yang baru menerima 400 juta rupiah. Hal tersebut harus segera ditangani agar dana yang dijatahkan dapat diterima penuh oleh masingmasing LKM UED-SP di Kecamatan Rambah, sehingga program yang dilaksanakan dapat berjalan maksimal sesuai dengan tujuan awal berdirinya LKM UED-SP.

\section{Kinerja Jangkauan LKM UED-SP di Kecamatan Rambah}

\section{a. Rata-rata jumlah pinjaman}

Pertumbuhan rata-rata jumlah pinjaman per peminjam LKM UED SP Kecamatan Rambah ditampilkan pada Tabel 2. Pada Tabel 2 dijelaskan bahwa pertumbuhan rata-rata berdasarkan rata-rata jumlah pinjaman LKM UED-SP di Kecamatan Rambah berada di bawah 50 persen, bahkan ada beberapa yang memiliki rata-rata pertumbuhan negatif. Ratarata pertumbuhan total dari rata-rata jumlah pinjaman hanya sebesar 8,97 persen selama periode waktu 3 (tiga) tahun. Hal tersebut menunjukkan bahwa rata-rata jumlah pinjaman per peminjam pada LKM UED-SP di Kecamatan Rambah relatif konstan setiap tahunnya, karena besarnya rata-rata jumlah pinjaman tidak berubah signifikan. Seperti pada LKM UED-SP Desa Rambah Tengah Utara yang memiliki rata-rata pertumbuhan terendah hanya sebesar $-0,47$ persen. Selama periode waktu 3 (tiga) tahun rata-rata pertumbuhan di desa tersebut hanya sebesar Rp.143.946 rupiah, dari sebelumnya tahun 2012 sebesar Rp.10.233.766 pada tahun 2012 menjadi Rp.10.089.820 pada tahun 2015.

Peningkatan rata-rata jumlah pinjaman yang konstan tersebut dikarenakan adanya peningkatan jumlah pinjaman dari para pemanfaat/peminjam yang berbanding lurus dengan rata-rata jumlah pinjaman. Sehingga diduga jika pada LKM UED-SP mengalami peningkatan jumlah pinjaman telah mengabaikan tujuan awal pendirian LKM UED-SP sebagai upaya pemberdayaan masyarakat dengan meminjamkan kepada 
masyarakat berpenghasilan rendah. Orientasi LKM UED-SP tersebut diduga telah berubah untuk mengejar keuntungan. Sebaliknya, UEDSP di beberapa desa yang memilki rata-rata jumlah pinjaman yang relatif konstan bahkan mengalami sedikit penurunan, artinya beberapa LKM tersebut tetap konsisten dalam memperhatikan kedalaman jangkauan. Namun apabila UED-SP memiliki rata-rata jumlah pinjaman konstan namun tinggi seperti pada LKM UED-SP Desa Rambah Tengah Utara dengan rata-rata pinjaman 10 juta rupiah dan UED-SP Desa Sialang Jaya dengan rata-rata pinjaman sebesar 9 juta rupiah. Sejak awal berdiri UED-SP tersebut diduga sudah meminjamkan kepada masyarakat yang berpenghasilan tinggi, bahkan membatasi akses kepada masyarakat kurang mampu (memiliki penghasilan lebih rendah). Berdasarkan informasi yang diperoleh dari LKM UED-SP di Kecamatan Rambah, beberapa LKM UED-SP memberikan kredit kepada masyarakat pemilik usaha yang relatif besar guna meminimalisasi tunggakan dan menjaga keberlanjutan LKM.

\section{b. Umur Lembaga Keuangan Mikro}

Semakin tua umur suatu lembaga diharapkan akan semakin mematangkan lembaga tersebut dan akan meningkatkan kinerja jangkauan LKM UED-SP. Apabila pendapatan yang diperoleh meningkat maka UED-SP memiliki kemampuan yang lebih besar dalam memberikan pinjaman kepada lebih banyak masyarakat, sehingga jangkauan LKM akan semakin luas. Dengan begitu LKM juga berpeluang dalam menjaga kedalaman jangkauannya. LKM tersebut berpotensi dalam meningkatkan modal, karena semakin tua umur LKM diharapkan akan semakin tinggi pendapatan yaang diperoleh. Jika LKM tetap konsisten pada tujuan awal sebagai upaya pemberdayaan maka akan semakin banyak masyarakat miskin yang terbantu.

Semakin tua umur LKM tersebut juga akan semakin mendatangkan masalah yang lebih kompleks, sehingga bagi LKM UED-SP yang tidak dapat menyelesaikan masalah, maka berakibat pada kehancuran dan penurunan kinerja LKM. Hal tersebut dikarenakan selain pendapatan yang meningkat, bertambahnya umur juga akan meningkatkan biaya operasional. Seperti yang terjadi pada beberapa LKM UED-SP di Kecamatan Rambah yang diduga telah keluar dari tujuan awal pendiriannya. Pada subbab sebelumnya telah dijelaskan bahwa LKM UED-SP Rambah Tengah Utara dan Sialang Jaya yang konsisten memiliki rata-rata jumlah pinjaman tertinggi. Sedangkan LKM UED-SP Rambah Tengah Hilir memiliki pertumbuhan rata-rata pinjaman yang tertinggi. UED-SP di desa tersebut diduga lebih mengutamakan pemanfaat/peminjam dengan penghasilan yang besar daripada masyarakat yang memiliki penghasilan kecil, dengan alasan untuk keberlanjutan LKM UEDSP.

Tabel 3. Pertumbuhan ROA pada LKM UED-SP di Kecamatan Rambah 2012-2015

\begin{tabular}{clrrr}
\hline \multirow{2}{*}{ No UED-SP } & \multicolumn{1}{c}{ Nilai Rasio ROA $(\%)$} & \multicolumn{2}{c}{$\begin{array}{c}\text { Pertumbuhan Rata- } \\
\text { rata }(\%)\end{array}$} \\
\cline { 3 - 4 } 1 & Babussalam & 2012 & 2015 & $-3,95$ \\
2 & Pematang Berangan & 1,21 & 6,356 & 138,28 \\
3 & Tanjung Belit & 2,849 & 5,38 & 12,68 \\
4 & Pasir Baru & 5,289 & 3,933 & $-25,27$ \\
5 & Sialang Jaya & 2,14 & 1,28 & $-27,21$ \\
6 & Koto Tinggi & 3,42 & 0,393 & 1,04 \\
7 & Rambah Tengah Barat & 5,428 & 3,527 & $-33,59$ \\
8 & Rambah Tengah Hilir & 14,283 & $-0,042$ & $-14,70$ \\
9 & Suka Maju Rambah & 10,638 & 7,986 & $-8,40$ \\
10 & Pasir Maju & 9,555 & 7,957 & $-3,20$ \\
11 & Rambah Tengah Utara & 4,762 & 8,638 & 2,42 \\
12 & Pasir Pengaraian & 2,904 & 5,108 & 102,56 \\
\hline Jumlah & 69,52 & 11,839 & $-3,44$ \\
\hline
\end{tabular}

Sumber: Laporan keuangan LKM UED-SP Kecamatan Rambah 2012-2015 (Diolah) 
LKM tersebut menganggap bahwa masyarakat miskin akan mengakibatkan peningkatan resiko pada keberlanjutan lembaga keuangan.

\section{c. Nilai Rasio ROA}

Pertumbuhan rasio ROA pada LKM UED-SP di Kecamatan Rambah dapat dilihat pada Tabel 3. Berdasarkan Tabel 3 di atas, secara keseluruhan rata-rata nilai rasio ROA UED-SP di Kecamatan Rambah sudah berada di atas standar BI. Berdasarkan Peraturan Bank Indonesia No.6/9/PBI/2004, Nilai standar terbaik ROA adalah ROA $\geq 1,5 \%$. Namun jika dilihat pada tahun 2015 ada beberapa LKM UED-SP yang memilki rasio keuangan di bawah standar BI, yaitu nilai ROA UED-SP Desa Pasir Baru sebesar 1,28 persen, ROA UED-SP Desa Sialang Jaya sebesar 0,393 dan ROA UED-SP Desa Rambah Tengah Barat sebesar -0,042. Rata-rata rasio ROA standar BI dapat menunjukkan efisiensi LKM UED-SP tersebut dan menginformasikan bahwa secara finansial pada tahun 2015 ada dua desa yang menunjukkan LKM belum efisien yaitu LKM UED-SP Desa Sialang Jaya dan Desa Rambah Tengah Barat. Sehingga dua LKM tersebut harus mendapat perhatian lebih. Karena jika tidak diperhatikan akan mempengaruhi keberlanjutan LKM tersebut yang bisa mengakibatkan tujuan berdirinya LKM tidak akan terwujud.

Berdasarkan teori kedalaman jangkauan, nilai ROA yang tinggi akan berpengaruh negatif terhadap kedalaman jangkauan (Handayani, 2013). LKM yang telah sesuai dengan tujuan awal (sebagai upaya pemberdayaan masyarakat) tidak memiliki orientasi yang tinggi terhadap profitabilitas, bahkan LKM akan mengeluarkan biaya operasional yang besar untuk mewujudkan visinya. LKM yang bertujuan sebagai fungsi sosial pemberdayaan masyarakat akan memiliki resiko keuangan yang lebih tinggi, seperti tunggakan kredit yang tinggi pada LKM UED-SP di Kecamatan Rambah. Oleh sebab itu, meskipun LKM UED-SP diharuskan untuk memperhatikan keberlanjutannya (sustainabilitas) dengan cara memperhatikan profitabilitas, akan tetapi tujuan dari LKM UED-SP (sebagai fungsi sosial pemberdayaan) tidak boleh dilupakan. Dengan kata lain, harus ada keseimbangan antara tujuan pemberdayaan dan profitabilitas.

Tabel 4. Pertumbuhan jumlah dan proporsi peminjam sektor perdagangan pada LKM UED-SP di Kecamatan Rambah selama 2014-2015

\begin{tabular}{|c|c|c|c|c|c|c|c|}
\hline \multirow{3}{*}{$\begin{array}{l}\mathrm{N} \\
\mathrm{O}\end{array}$} & \multirow{3}{*}{ UED-SP } & \multicolumn{6}{|c|}{ Peminjam Sektor Perdagangan (Orang) } \\
\hline & & \multicolumn{2}{|c|}{ Jumlah (Orang) } & \multirow{2}{*}{$\begin{array}{l}\text { Pertumbuhan } \\
\text { Rata-rata }(\%)\end{array}$} & \multicolumn{2}{|c|}{ Proporsi (\%) } & \multirow{2}{*}{$\begin{array}{l}\text { Pertumbuhan } \\
\text { Rata-rata }(\%)\end{array}$} \\
\hline & & 2012 & 2015 & & 2012 & 2015 & \\
\hline 1 & Babussalam & 205 & 337 & 21,46 & 34,34 & 42,23 & 7,66 \\
\hline 2 & Pematang Berangan & 162 & 330 & 34,57 & 35,92 & 48,18 & 11,37 \\
\hline 3 & Tanjung Belit & 62 & 99 & 19,89 & 25,83 & 22,76 & $-3,97$ \\
\hline 4 & Pasir Baru & 7 & 63 & 266,67 & 2,25 & 15,99 & 203,47 \\
\hline 5 & Sialang Jaya & 2 & 73 & 1183,33 & 1,20 & 33,18 & 890,23 \\
\hline 6 & Koto Tinggi & 26 & 191 & 211,54 & 9,15 & 46,47 & 135,87 \\
\hline 7 & Rambah Tengah Barat & 5 & 63 & 386,67 & 3,25 & 28,64 & 260,67 \\
\hline 8 & Rambah Tengah Hilir & 6 & 32 & 144,44 & 6,74 & 13,06 & 31,25 \\
\hline 9 & Suka Maju Rambah & 8 & 96 & 366,67 & 5,19 & 30,38 & 161,60 \\
\hline 10 & Pasir Maju & 0 & 16 & 533,33 & 0,00 & 7,05 & 234,95 \\
\hline 11 & Rambah Tengah Utara & 41 & 87 & 37,40 & 26,62 & 51,79 & 31,50 \\
\hline 12 & Pasir Pengaraian & 29 & 338 & 355,17 & 10,07 & 82,24 & 238,90 \\
\hline \multicolumn{2}{|c|}{ Jumlah } & 553 & 1725 & 70,64 & 160,57 & 421,96 & 54,26 \\
\hline
\end{tabular}

Sumber: Laporan keuangan LKM UED-SP Kecamatan Rambah 2012-2015 (Diolah) 


\section{d. Peminjam dari Sektor Perdagangan}

Pada Tabel 4 terlihat pertumbuhan peminjam sektor perdagangan pada LKM UED-SP di Kecamatan Rambah terhadap total peminjam.

Pada Tabel 4 menunjukkan data proporsi peminjam sektor perdagangan LKM UED-SP di Kecamatan Rambah. Secara Keseluruhan proporsi rata-rata jumlah peminjam sektor perdagangan di Kecamatan Rambah tumbuh sebesar 54,26 persen selama periode waktu 3 tahun. Artinya semangat masyarakat Kecamatan Rambah untuk meningkatkan usaha perdagangan semakin tinggi setiap tahunnya. UED-SP Desa Sialang Jaya menjadi desa yang memiliki pertumbuhan proporsi pinjaman paling signifikan yaitu sebesar 890,23 persen. Artinya UED-SP Desa Sialang Jaya mulai menjangkau sektor perdagangan.

Hanya terdapat satu UED-SP yang memiliki pertumbuhan rata-rata proporsi negatif yaitu pada LKM UED-SP Desa Tanjung Belit dan sekaligus menjadi nilai pertumbuhan ratarata terendah. Artinya Pertumbuhan rata-rata proporsi jumlah peminjam dari sektor pertanian tidak sebanding dengan pertumbuhan rata-rata proporsi dari sektor lain. Hal ini dikarenakan Desa Tanjung Belit lebih didominasi dari sektor perkebunan. Pada tahun 2015 proporsi jumlah peminjam sektor perdagangan yang tertinggi berada pada LKM UED-SP Kelurahan Pasir Pengaraian yaitu sebesar 82,24 persen. Hal itu disebabkan karena letak geografis Kelurahan Pasir Pengaraian berada di pusat ibukota Kabupaten Rokan Hulu. Banyak masyarakat ibukota yang memiliki usaha dari sektor perdagangan dikarenakan minimnya lahan pertanian di daerah tersebut.

Kinerja LKM UED-SP Kelurahan Pasir Pengaraian lebih dalam jangkauannya dari pada LKM UED-SP pada daerah lain di Kecamatan Rambah. Hal ini terjadi karena proporsi pinjaman sektor perdagangan di daerah tersebut adalah yang tertinggi, dan sektor perdagangan merupakan tempat masuknya usaha ekonomi mikro. Sedangkan usaha mikro merupakan objek dari pemberdayaan masyarakat, karena usaha mikro merupakan usaha yang dikelola oleh masyarakat yang butuh pemberdayaan berupa bantuan keuangan mikro. Berdasarkan banyaknya peminjam dari sektor perdagangan, LKM UED-SP di Desa Tanjung Belit lebih dangkal jangkauannya karena UED-SP Desa Tanjung Belit lebih sedikit memililki peminjam sektor perdagangan, dibuktikan dengan rendahnya pertumbuhan rata-rata proporsi peminjam sektor perdagangan. Namun peminjam dari sektor perdagangan bukan satusatunya indikator dalam menilai kedalaman jangkauan. Masih ada indikator lain yang dapat menilai kedalaman jangkauan LKM, seperti peminjam dari sektor pertanian.

Tabel 5. Pertumbuhan jumlah dan proporsi peminjam sektor pertanian pada LKM UED-SP di Kec. Rambah

\begin{tabular}{|c|c|c|c|c|c|c|c|}
\hline \multirow{3}{*}{$\begin{array}{l}\mathrm{N} \\
\mathrm{O}\end{array}$} & \multirow{3}{*}{ UED-SP } & \multicolumn{6}{|c|}{ Peminjam Sektor Pertanian (Orang) } \\
\hline & & \multicolumn{2}{|c|}{ Jumlah (Orang) } & \multirow{2}{*}{$\begin{array}{l}\text { Pertumbuhan } \\
\text { Rata-rata }(\%)\end{array}$} & \multicolumn{2}{|c|}{ Proporsi $(\%)$} & \multirow{2}{*}{$\begin{array}{l}\text { Pertumbuhan } \\
\text { Rata-rata (\%) }\end{array}$} \\
\hline & & 2012 & 2015 & & 2012 & 2015 & \\
\hline 1 & Babussalam & 54 & 75 & 12,96 & 9,05 & 9,40 & 1,30 \\
\hline 2 & Pematang Berangan & 12 & 12 & 0,00 & 2,66 & 1,75 & $-11,39$ \\
\hline 3 & Tanjung Belit & 128 & 204 & 19,79 & 53,33 & 46,90 & $-4,02$ \\
\hline 4 & Pasir Baru & 249 & 324 & 10,04 & 80,06 & 82,23 & 0,90 \\
\hline 5 & Sialang Jaya & 106 & 145 & 12,26 & 63,47 & 65,91 & 1,28 \\
\hline 6 & Koto Tinggi & 115 & 191 & 22,03 & 40,49 & 46,47 & 4,92 \\
\hline 7 & Rambah Tengah Barat & 92 & 149 & 20,65 & 59,74 & 67,73 & 4,46 \\
\hline 8 & Rambah Tengah Hilir & 71 & 202 & 61,50 & 79,78 & 82,45 & 1,12 \\
\hline 9 & Suka Maju Rambah & 107 & 210 & 32,09 & 69,48 & 66,46 & $-1,45$ \\
\hline 10 & Pasir Maju & 79 & 211 & 55,70 & 89,77 & 92,95 & 1,18 \\
\hline 11 & Rambah Tengah Utara & 34 & 36 & 1,96 & 22,08 & 21,56 & $-0,79$ \\
\hline 12 & Pasir Pengaraian & 28 & 29 & 1,19 & 9,72 & 7,06 & $-9,14$ \\
\hline \multicolumn{2}{|c|}{ Jumlah } & 1075 & 1788 & 22,11 & 579,64 & 590,86 & 0,65 \\
\hline
\end{tabular}

Sumber: Laporan keuangan LKM UED-SP Kecamatan Rambah 2012-2015 (Diolah) 


\section{f. Peminjam dari Sektor Pertanian}

Di bawah ini disajikan Tabel 5 mengenai pertumbuhan peminjam sektor pertanian pada LKM UED-SP di Kecamatan Rambah Berdasarkan Tabel 5, secara keseluruhan proporsi rata-rata jumlah pinjaman sektor pertanian di Kecamatan Rambah hanya meningkat 0,65 persen dalam periode waktu 3 (tiga) tahun. Terdapat 5 (lima) UED-SP yang memiliki pertumbuhan rata-rata proporsi peminjam sektor pertanian yang negatif, yaitu UED-SP pada Desa Pematang Berangan, Desa Tanjung Belit, Desa Suka Maju Rambah, Desa Rambah Tengah Utara dan Kelurahan pasir Pengaraian. Desa Pematang Berangan memiliki nilai pertumbuhan rata-rata proporsi peminjam sektor pertanian sebesar $-11,39$ persen. Artinya pertumbuhan rata-rata jumlah peminjam dari sektor pertanian tidak sebanding dengan pertumbuhan rata-rata dari sektor lainnya. Dengan kata lain, peningkatan jumlah peminjam dari sektor pertanian lebih sedikit daripada peningkatan jumlah peminjam dari sektor non pertanian. Seperti yang terjadi pada LKM Desa Tanjung Belit, walaupun pertumbuhan rata-rata jumlah peminjam per tahun dari sektor pertanian meningkat sebesar
19,79 persen namun pertumbuhan rata-rata rasio jumlah peminjam mengalami penurunan sebesar $-4,02$ persen.

Jumlah peminjam sektor pertanian tertinggi pada tahun 2015 berada pada LKM UED-SP Desa Rambah Tengah Hilir yaitu sebesar 82,45 persen. Hal itu disebabkan karena peminjam pada desa tersebut didominasi oleh peminjam pertanian. Banyak masyarakat di Desa Rambah Tengah Hilir yang memiliki usaha perkebunan sawit dan karet. Sedangkan peningkatan pertumbuhan rata-rata proporsi jumlah peminjam sektor pertanian yang tertinggi berada pada LKM UED-SP Desa Koto Tinggi yaitu sebesar 4,92 persen. Artinya desa tersebut mulai menjangkau lebih banyak masyarakat tani. Sedangkan UED-SP Desa Pematang Berangan memiliki pertumbuhan proporsi peminjam yang terendah, yaitu sebesar -11,11 persen dan Desa Pasir Pengaraian sebesar -11,16 persen. UED-SP pada kedua wilayah tersebut tidak terjadi peningkatan jumlah peminjam dari sektor pertanian karena letak geografisnya yang berada di wilayah ibukota kabupaten, sehingga sebagian besar masyarakatnya melakukan usaha pada sektor perdagangan dan jasa.

Tabel 6. Pertumbuhan jumlah dan proporsi peminjam wanita pada LKM UED-SP di Kecamatan Rambah selama 2014-2015

\begin{tabular}{|c|c|c|c|c|c|c|c|}
\hline \multirow{3}{*}{$\begin{array}{l}\mathrm{N} \\
\mathrm{o}\end{array}$} & \multirow{3}{*}{ UED-SP } & \multicolumn{6}{|c|}{ Peminjam Wanita (Orang) } \\
\hline & & \multicolumn{2}{|c|}{ Jumlah (Orang) } & \multirow{2}{*}{$\begin{array}{l}\text { Pertumbuhan } \\
\text { Rata-rata (\%) }\end{array}$} & \multicolumn{2}{|c|}{ Proporsi $(\%)$} & \multirow{2}{*}{$\begin{array}{c}\text { Pertumbuha } \\
\text { n Rata-rata } \\
(\%)\end{array}$} \\
\hline & & 2012 & 2015 & & 2012 & 2015 & \\
\hline 1 & Babussalam & 235 & 352 & 16,60 & 39,36 & 29,45 & $-8,39$ \\
\hline 2 & Pematang Berangan & 166 & 265 & 19,88 & 36,81 & 38,69 & 1,70 \\
\hline 3 & Tanjung Belit & 53 & 98 & 28,30 & 22,08 & 22,53 & 0,68 \\
\hline 4 & Pasir Baru & 56 & 75 & 11,31 & 18,01 & 19,04 & 1,91 \\
\hline 5 & Sialang Jaya & 34 & 44 & 9,80 & 20,36 & 20 & $-0,59$ \\
\hline 6 & Koto Tinggi & 114 & 149 & 10,23 & 40,14 & 36,25 & $-3,23$ \\
\hline 7 & Rambah Tengah Barat & 31 & 51 & 21,51 & 20,13 & 23,18 & 5,05 \\
\hline 8 & Rambah Tengah Hilir & 18 & 44 & 48,15 & 20,22 & 17,96 & $-3,73$ \\
\hline 9 & Suka Maju Rambah & 34 & 75 & 40,20 & 22,08 & 23,73 & 2,49 \\
\hline 10 & Pasir Maju & 24 & 62 & 52,78 & 27,27 & 27,31 & 0,05 \\
\hline 11 & Rambah Tengah Utara & 37 & 44 & 6,31 & 24,03 & 26,35 & 3,22 \\
\hline 12 & Pasir Pengaraian & 114 & 179 & 19,01 & 39,58 & 43,55 & 3,34 \\
\hline \multicolumn{2}{|c|}{ Jumlah } & 916,0 & $1.438,0$ & 19,00 & 330,07 & 328,04 & $-0,21$ \\
\hline
\end{tabular}

Sumber: Laporan keuangan LKM UED-SP Kecamatan Rambah 2012-2015 (Diolah) 
Berdasarkan banyaknya jumlah peminjam dari sektor pertanian, maka LKM UED-SP pada Desa Rambah Tengah Hilir memiliki kinerja jangkauan yang lebih dalam jika dibandingkan dengan desa lainnya. Hal tersebut dikarenakan pada Desa Rambah Tengah Hilir memiliki proporsi pinjaman dari sektor pertanian yang tertinggi. Namun realita yang terjadi menunjukkan bahwa peminjam LKM UED-SP dari sektor pertanian di Kecamatan Rambah Kabupaten Rohul adalah petani yang memiliki pendapatan besar, bukan petani miskin yang menjadi objek pemberdayaan. Pada umumnya petani yang berusaha dalam subsektor perkebunan karet dan sawit, memiliki penghasilan yang relatif lebih tinggi dari petani yang berusaha di subsektor lain (seperti subsektor pangan). Oleh karena itu peminjam dari sektor pertanian yang berada di Kecamatan Rambah tidak tepat digunakan sebagai indikator kedalaman jangkauan keuangan mikro.

\section{f. Peminjam Wanita}

Peminjam wanita adalah jumlah peminjam wanita yang berada di Kecamatan Rambah secara keseluruhan dari peminjam total. Berdasarkan penelitian yang dilakukan oleh Olivares-Polanco (2005), peminjam wanita berpengaruh positif terhadap kedalaman jangkauan karena peminjam wanita dianggap lebih miskin daripada peminjam laki-laki. Jumlah peminjam wanita di Kecamatan Rambah dapat dilihat pada Tabel 6.

Berdasarkan Tabel 6 dapat diketahui bahwa pertumbuhan rata-rata proporsi jumlah peminjam wanita pada LKM UED-SP secara keseluruhannya berada di bawah 50 persen. Bahkan terdapat beberapa LKM yang memiliki pertumbuhan rata-rata negatif, artinya LKM UED-SP tersebut mengalami penurunan proporsi jumlah peminjam wanita. Penurunan pertumbuhan rata-rata proporsi jumlah peminjam wanita disebabkan karena peningkatan jumlah peminjam wanita yang tidak sebanding dengan jumlah peminjam lakilaki. Dengan kata lain, peningkatan jumlah peminjam wanita lebih sedikit daripada peningkatan jumlah peminjam laki-laki. Seperti pada LKM UED-SP Desa Pasir Maju yang mengalami pertumbuhan rata-rata jumlah peminjam wanita tertinggi yaitu sebesar 52,78 persen. Namun pertumbuhan rata-rata proporsi peminjam wanita pada LKM tersebut hanya sebesar 0,05 persen.

Jumlah peminjam wanita pada Desa Babussalam merupakan jumlah yang tertinggi pada LKM UED-SP di Kecamatan Rambah, namun pertumbuhan rata-rata proporsinya menjadi yang terendah yaitu sebesar $-8,39$ persen. Berdasarkan proporsi peminjam wanita tahun 2015, maka LKM UED-SP pada Kelurahan Pasir Pengaraian merupakan UEDSP yang memiliki proporsi peminjam wanita tertinggi yaitu sebesar 43,55 persen dan disusul oleh LKM UED-SP Desa Pematang Berangan yaitu sebesar 38,69 persen. Hal itu terjadi karena kedua LKM tersebut berada pada daerah perkotaan yang memiliki mata pencaharian dalam sektor jasa dan perdagangan, sehingga peluang masuknya pelaku usaha wanita lebih banyak. Sedangkan pertumbuhan rata-rata proporsi peminjam wanita tertinggi terjadi di LKM UED-SP Desa Pasir Baru yaitu sebesar 5,05 persen.

Berdasarkan teori kedalaman jangkauan maka LKM UED-SP yang ada di Kelurahan Pasir Pengaraian memiliki kinerja yang lebih baik dari LKM UED-SP di desa lainnya, karena LKM di daerah tersebut sudah menjangkau peminjam wanita yang menjadi sebagai objek pemberdayaan. Namun, Sebagian besar peminjam wanita yang menerima pinjaman kredit di Kecamatan Rambah Kabupaten Rokan Hulu bukan termasuk peminjam miskin yang menjadi objek pemberdayaan. Beberapa peminjam wanita hanya mengatasnamakan pinjaman untuk kebutuhan keluarga, bukan semata-mata karena kebutuhan pribadi. Berdasarkan informasi dari pengelola LKM UED-SP di Kecamatan Rambah, beberapa dari mereka (peminjam wanita) meminjam uang hanya untuk menutupi hutang usaha suami di bank maupun kepada rentenir. Sehingga peminjam wanita tidak relevan untuk digunakan sebagai indikator kedalaman jangkauan keuangan mikro.

Secara keseluruhan rata-rata pertumbuhan proporsi peminjam wanita mengalami penurunan sebesar $-0,21$ persen selama periode waktu 3 (tiga) tahun. Sehingga secara keseluruhan LKM UED-SP di Kecamatan Rambah masih didominasi oleh peminjam pria. 


\section{Pemilihan Model Estimasi Regresi Data Panel}

a. Uji Chow (Chow test)

Hasil estimasi uji Chow dapat dilihat di Tabel 7.

Tabel 7. Hasil estimasi uji Chow

Redundant Fixed Effects Tests

Equation: Untitled

Test cross-section fixed effects

\begin{tabular}{lccc}
\hline Effects Test & Statistic & d.f. & Prob. \\
Cross-section F & $3,359,070$ & $(11,31)$ & 0,0038 \\
Cross-section Chi-square & $37,669,514$ & 11 & 0,0001 \\
\hline
\end{tabular}

Berdasarkan hasil estimasi pada Tabel 7 nilai untuk Prob. Cross Section F adalah 0,0038, artinya $\mathrm{H} 1$ diterima dan $\mathrm{H}_{0}$ ditolak karena Prob. Cross Section F < 0,05. Pada Tabel 7 diperoleh F-statistik adalah 3,359070, dengan nilai F-tabel pada df (11,31) $\alpha=5 \%$ adalah 2,11, sehingga nilai F-statistik > F-tabel, maka $\mathrm{H}_{0}$ ditolak. Hasil pengujian ini menunjukkan bahwa model Fixed Effect lebih baik digunakan dari pada model Pooled Least Square atau Common Effect. Artinya efek wilayah (desa/kelurahan) dari data yang digunakan dalam penelitian ini berpengaruh terhadap model. Intersep untuk setiap unit cross section berbeda (tidak konstan).

\section{b. Uji Hausman (Hausman Test)}

Hasil estimasi uji Hausman dapat dilihat pada Tabel 8 di bawah ini.

Tabel 8. Hasil estimasi uji Hausman

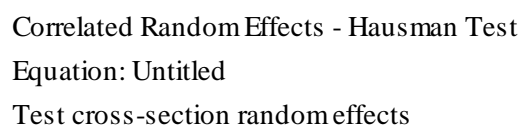

Output estimasi pada Tabel 8 menunjukkan bahwa hasil uji haussman signifikan dengan chi square 11,328622 dan nilai prob. sebesar 0.0452 berada di bawah 5 persen. Sementara chi-Square tabel lima variabel dependen dengan $\mathrm{df}=\mathrm{k}=5$ dengan signifikansi 0,05 adalah
11.070, sehingga dapat disimpulkan hipotesis nol ditolak karena nilai chi-square statistik uji haussman > chi-square tabel. Artinya sekurangkurangnya terdapat satu intersep pada unit cross-section yang tidak sama sehingga model yang cocok digunakan dalam regresi data panel adalah Fixed Effect Model (FEM). Dengan kata lain, bahwa residual model regresi tidak memiliki hubungan antar waktu dan antar objek. Sehingga nilai varian error tiap cross section adalah konstan, namun intersep crosssection berbeda tiap objek.

\section{Uji Hipotesis Penelitian}

Berdasarkan hasil uji asumsi klasik yang telah dilakukan diketahui bahwa data terdistribusi normal dan tidak terdapat multikoleniaritas, Oleh karena itu data yang tersedia telah memenuhi syarat yang digunakan dalam model regresi data panel untuk mengetahui faktorfaktor yang mempengaruhi kedalaman jangkauan yang diwakili proksi rata-rata jumlah pinjaman (AOL). Sesuai dengan hasil estimasi regresi data panel dengan model Fixed Effect (FEM) pada Lampiran 1, persamaan model regresi yang dapat ditulis dalam bentuk persamaan linear sebagai berikut:

AOLit $=(3742939,00+$ Koefisien masing-masing LKM UED-SP) + 660653,80*AGE - 55072,47*ROA $15867,94 *$ DAGANG $+11557,95 *$ TANI + $2787,13 *$ WANITA + it

\section{a. Hasil Uji koefisien $\mathbf{R}^{\mathbf{2}}$}

Berdasarkan hasil estimasi regresi data panel pada Lampiran 1 diperoleh hasil bahwa $\mathrm{R}^{2}$ sebesar 0,776688. Hal ini menunjukkan bahwa sebesar 77,67 persen dari variasi umur lembaga (AGE), ROA, proporsi peminjam sektor perdagangan (DAGANG), proporsi peminjam sektor pertanian (TANI), jumlah peminjam wanita (WANITA) dan sisanya sebesar 22,33 persen dijelaskan oleh variabel lain yang tidak diteliti dalam penelitian ini.

\section{b. Uji signifikasi Simultan (Uji F- statistik)}

Berdasarkan hasil uji F-statistik pada Lampiran 1 nilai Prob.(F-statistic) adalah 0,000003 < $0,05(5 \%)$. Nilai F-hitungnya sebesar 6,738697 dan F-tabel $(\alpha=5 \%)$ dengan $n=48, k=17$ adalah 2,52, sehingga F-hitung > F-tabel. Artinya dapat disimpulkan bahwa variabel umur lembaga (AGE), ROA, proporsi peminjam 
sektor perdagangan (DAGANG), proporsi peminjam sektor pertanian (TANI), jumlah peminjam wanita (WANITA) secara bersamasama (simultan) berpengaruh signifikan terhadap variabel rata-rata jumlah pinjaman (AOL) pada tingkat kepercayaan $95 \%(\alpha=5 \%)$

\section{c. Uji signifikasi individual (Uji t-statistik)}

Di bawah ini ditampilkan hasil analisis uji signifikansi individual (uji $\mathrm{t}$-statistik) pada Tabel 9 sebagai berikut.

Tabel 9. Hasil uji regresi individual (uji t)

\begin{tabular}{|c|c|c|c|c|}
\hline Variabel & t-statistik & t-tabel & Prob. & Keterangan \\
\hline $\mathrm{C}$ & 0,720044 & 20,395 & 0,4769 & Tdk Signifikan \\
\hline AGE_(Tahun)_X1 & $2,420,044$ & 20,395 & 0,0216 & Signifikan \\
\hline ROA_(\%)_X2 & $-0,498711$ & 20,395 & 0,6215 & Tdk Signifikan \\
\hline DAGANG_(\%)_X3 & $-0,874943$ & 20,395 & 0,3883 & Tdk Signifikan \\
\hline TANI_(\%)_X4 & 0,114210 & 20,395 & 0,9098 & Tdk Signifikan \\
\hline WANITA_(Orang)_X5 & 0,199789 & 20,395 & 0,8430 & Tdk Signifikan \\
\hline
\end{tabular}

Tabel 9 menunjukkan hasil uji parsial (uji t) variabel independen terhadap variabel dependen. Nilai t-tabel $(\alpha=5 \%)$ dengan $\mathrm{df}=\mathrm{n}$ $\mathrm{k}=31$ adalah 2,0395. Berdasarkan tabel tersebut dapat dilihat bahwa hanya satu variabel yang berpengaruh signifikan, yaitu variabel umur LKM UED-SP.

\section{Interpretasi Hasil Estimasi \\ a. Konstanta}

Dari hasil estimasi dapat dilihat besar konstanta atau intersep antar LKM UED-SP memiliki nilai yang berbeda-beda antar LKM namun sama antarwaktu (time invariant) dan konstanta atau intersep pada model penelitian tidak signifikan secara statistik. Perbedaan intersep ini menggambarkan adanya perbedaan sifat dan karakteristik antar LKM UED-SP. Sesuai dengan informasi yang dihimpun pada LKM UED-SP di Kecamatan Rambah, setiap LKM UED-SP memiliki karakteristik berbeda baik itu kondisi geografis, budaya masyarakat, perbedaan sarana dan prasarana, perbedaan manajemen dan perbedaan dukungan dari pemerintah setempat.

Pada Lampiran 1 dapat diketahui bahwa nilai intersep yang paling besar terdapat pada LKM UED SP Rambah Tengah Utara dengan intersep sebesar 3083201,00. Hal ini menunjukkan, jika nilai variabel bebas diasumsikan sama dengan nol atau terjadi perubahan antar variabel bebas (AGE, ROA, DAGANG, TANI, WANITA), maka koefisien individu (rata-rata pinjaman) di UED-SP Rambah Tengah Utara adalah sebesar Rp.3.083.201,0 + Rp.3.742.939,00 (C). Sedangkan, UED-SP Babussalam memiliki intersep paling kecil dengan nilai sebesar 2657388,0. Angka tersebut menginterpretasikan bahwa semua variabel independen yang digunakan sangat berpengaruh dalam menjelaskan variabel dependen (AOL). Jika semua variabel bebas sama dengan nol dan jika terjadi perubahan antar variabel bebas maka koefisien individu (nilai rata-rata pinjaman) UED-SP Babussalam adalah Rp.-2.657.388,00 + Rp.3.742.939,00 (C).

\section{b. Pengaruh Umur (AGE) Lembaga Keuangan Mikro terhadap Kedalaman Jangkauan Keuangan Mikro.}

Berdasarkan hipotesis, umur Lembaga Keuangan Mikro (LKM) berpengaruh negatif terhadap kedalaman jangkauan. Semakin dewasa umur suatu LKM maka akan semakin baik kinerja keuangannya dan semakin baik kinerja jangkauan target grup yang dilayani, sehingga jangkauannya cenderung semakin luas dan bukan semakin dalam (Handayani, 2013). Hasil estimasi model pada LKM UED-SP Rohul sesuai dengan hipotesis, yakni variabel umur (AGE) LKM UED-SP mempunyai koefisien positif sebesar 660.653,80. Hal tersebut dapat diinterpretasikan bahwa setiap pertambahan umur LKM selama 1 (satu) tahun akan menyebabkan kenaikan nilai rata-rata jumlah pinjaman kredit yang diberikan kepada nasabah sebesar Rp. 660.653,80.

Berdasarkan uji t-statistik, variabel umur lembaga (AGE) berpengaruh signifikan terhadap kedalaman jangkauan. Tanda positif pada koefisien variabel ini mengungkapkan bahwa pertambahan umur UED-SP tidak menambah kedalaman jangkauan pada masyarakat yang lebih miskin atau usaha mikro yang dilayaninya. Hal ini diduga karena adanya hambatan dari peraturan perbankan yang berlaku tidak lebih kondusif terhadap perkembangan jangkauan keuangan mikro terutama dalam hal kedalaman jangkauan (depth of outreach) (Handayani, 2013). Dalam 
melayani masyarakat, UED-SP melakukan kerjasama dengan beberapa bank konvensional. Salah satunya dengan meminta data calon nasabah/peminjam, apakah calon peminjam terbebas dari hutang bank atau tidak. LKM UED-SP hanya melayani masyarakat yang terbebas dari hutang bank. Kondisi tersebut akan mempengaruhi kinerja jangkauan UEDSP karena program pemberdayaan yang dijalankan dikhawatirkan akan semakin mendangkalkan jangkauan LKM meskipun jangkauannya semakin luas.

\section{c. Pengaruh Financial Self-Sustainability (ROA) terhadap Kedalaman Jangkauan Keuangan Mikro.}

Variabel financial self-sustainability yang diwakili ROA, mempunyai koefisien negatif sebesar 55072,47, artinya bahwa setiap kenaikan ROA pada masing-masing LKM UED-SP sebesar 1 (satu) persen akan menyebabkan penurunan rata-rata jumlah pinjaman kredit sebesar Rp.22.292,91 dengan asumsi variabel yang lain tetap (ceteris paribus). Berdasarkan uji t-statistik, variabel ROA berpengaruh tidak signifikan namun akan menyebabkan pengaruh positif terhadap kedalaman jangkauan meskipun hanya sedikit.

Koefisien ROA dari hasil regresi penelitian ini berlawanan dengan hipotesis yang menyatakan bahwa Financial self-sustainability yang diwakili oleh return on assets (ROA) berpengaruh negatif terhadap pencapaian kedalaman jangkauan, karena semakin miskin masyarakat yang dilayani, maka biaya yang dikeluarkan akan semakin besar. Hal itu menyebabkan lembaga keuangan yang memperhatikan kedalaman jangkauan lebih cenderung memiliki laba operasi yang kecil sehingga ROA menjadi rendah (Handayani, 2013). LKM yang fokus kepada pemberdayaan masyarakat miskin akan menghadapi resiko keuangan yang semakin tinggi, misalnya resiko tunggakan. Sebagai contoh UED-SP pada Desa Rambah Tengah Hilir yang mengalami pertumbuhan ROA negatif. Hal itu terjadi karena banyaknya tunggakan dari peminjam kredit. Berdasarkan keterangan dari pemerintah setempat, tingginya tunggakan disebabkan oleh masyarakat yang menganggap bahwa dana yang dipinjamkan merupakan hibah dari pemerintah. Hal itu berakibat pada kurangnya kesadaran masyarakat dalam membayar kredit.
Masyarakat lebih taat membayar kredit kepada rentenir dibandingkan pada UED-SP. Beberapa masyarakat di Kecamatan Rambah meminjam uang kepada UED-SP hanya untuk membayar hutang kepada rentenir. Kondisi tersebut akan menyebabkan berkurangnya cadangan uang LKM UED-SP karena cadangan uang yang ada dikhawatirkan akan habis untuk biaya operasional saja, seperti membayar gaji karyawan.

Pada penelitian ini, financial selfsustainability memberikan pengaruh positif, namun secara statitistik (uji t-statistik) tidak signifikan terhadap kedalaman jangkauan keuangan mikro yang diwakili proksi rata-rata jumlah pinjaman (AOL). Dengan demikian industri keuangan mikro (UED-SP) di Kabupaten Rokan Hulu dapat mengatasi tingginya biaya operasional pemberian kredit dalam nominal kecil dengan tidak mengurangi tingkat keuntungan. Hal ini dikarenakan LKM UED-SP mampu beroperasi dengan efisien. LKM UED-SP yang berada di Kecamatan Rambah mampu mendistribusikan kredit dengan baik kepada masyarakat yang membutuhkan pemberdayaan (distribusinya merata).

\section{d. Pengaruh Proporsi Peminjam Sektor Perdagangan terhadap Kedalaman Jangkauan Keuangan Mikro.}

Variabel proporsi peminjam sektor pertanian mempunyai koefisien negatif sebesar 15867,94. Angka tersebut dapat diinterpretasikan bahwa setiap kenaikan 1 persen nasabah dari sektor perdagangan akan menurunkan rata-rata jumlah pinjaman (AOL) sebesar Rp.15.867,00. Artinya sektor perdagangan yang menggunakan layanan UED-SP di Kecamatan Rambah merupakan pengusaha mikro yang tidak membutuhkan pinjaman terlalu besar, namun sangat membutuhkan bantuan finansial dalam pengembangan usahanya. Secara statistik variabel ini berpengaruh tidak signifikan, namun memberikan pengaruh positif terhadap kedalaman jangkauan dengan asumsi variabel yang lain tetap (ceteris paribus). Kondisi ini sesuai dengan hipotesis yang menyatakan bahwa variabel jumlah peminjam dari sektor perdagangan berpengaruh positif terhadap kedalaman jangkauan karena sektor perdagangan adalah sektor yang dominan dimiliki oleh usaha mikro (Handayani, 2013). 
Sektor perdagangan menjadi hal yang perlu mendapatkan perhatian yang lebih besar, melihat kondisi bahwa peminjam sektor perdagangan di Kecamatan Rambah didominasi oleh usaha mikro. Semakin banyak sektor perdagangan yang mendapatkan layanan keuangan mikro, maka akan semakin memperdalam jangkauan LKM UED-SP. Hal itu sesuai dengan salah satu prinsip utama keuangan mikro menurut CGAP (2004), yang menyatakan bahwa keuangan mikro adalah instrumen yang berdaya guna dalam melawan kemiskinan. Usaha mikro merupakan sektor yang sangat membutuhkan bantuan modal. Semakin banyak usaha mikro yang dilayani akan semakin mengurangi kemiskinan, karena akan tercipta usaha dan lapangan kerja yang baru.

\section{e. Pengaruh Proporsi Peminjam Sektor Pertanian terhadap Kedalaman Jangkauan Keuangan Mikro.}

Sesuai dengan hipotesis penelitian ini yang menyatakan bahwa proporsi peminjam sektor pertanian diduga akan berpengaruh positif terhadap kedalaman jangkauan. Semakin banyak jumlah peminjam pada sektor pertanian, artinya semakin banyak masyarakat tani yang dilayani. Variabel proporsi peminjam sektor pertanian mempunyai koefisien positif sebesar 11557,95 , artinya untuk setiap penambahan 1 (satu) persen rasio jumlah pinjaman dari sektor pertanian akan meningkatkan rata-rata pinjaman yang diberikan yaitu sebesar Rp.11.557,95. Secara statistik variabel proporsi peminjam sektor pertanian berpengaruh tidak signifikan (uji t-statistik) sehingga memiliki pengaruh yang sangat kecil. Namun akan berpengaruh negatif terhadap kedalaman jangkauan yang diwakili oleh proksi rata-rata jumlah pinjaman (AOL) dengan asumsi variabel yang lain tetap (ceteris paribus). Hal tersebut mengindikasikan bahwa semakin banyak masyarakat petani yang meminjam, maka akan semakin mendangkalkan kedalaman jangkauan.

Kondisi ini terjadi diduga karena lokasi kantor LKM UED-SP yang berada jauh dari pemukiman petani miskin sehingga sulit untuk dijangkau, juga adanya kebutuhan skema kredit berkarakteristik khusus yang belum disediakan oleh LKM UED-SP. Dengan kata lain, peminjam LKM UED-SP dari sektor pertanian di Kecamatan Rambah Kabupaten Rokan Hulu (Rohul) adalah petani yang memiliki pendapatan besar, bukan petani miskin yang menjadi objek pemberdayaan. Pada umumnya petani di Kecamatan Rambah yang menjadi pemanfaat/peminjam kredit merupakan petani dari subsektor perkebunan karet dan sawit, sehingga memiliki penghasilan yang relatif tinggi dari petani yang berusaha di subsektor lain (contohnya subsektor pangan). Sehingga apabila hal tersebut dibiarkan, maka dikhawatirkan LKM UED-SP akan kurang fokus kepada kedalaman jangkauan. LKM tersebut menjadi lebih fokus pada profitabilitas dan sustainabilitasnya.

\section{f. Pengaruh Jumlah Peminjam Wanita terhadap Kedalaman Jangkauan Keuangan Mikro.}

Variabel jumlah peminjam wanita merupakan variabel perwakilan jender yang diperoleh dari data peminjam wanita terhadap seluruh nasabah yang dimiliki oleh masing-masing LKM UEDSP di Kecamatan Rambah. Peminjam wanita berpengaruh positif terhadap kedalaman jangkauan karena peminjam wanita dianggap lebih miskin daripada peminjam laki-laki yang butuh pemberdayaan (Olivares-Polanco, 2005). Sedangkan koefisien variabel jumlah peminjam wanita (WANITA) berlawanan dengan hipotesis penelitian ini. Pada penelitian ini koefisien variabel WANITA menunjukkan angka yang positif yaitu sebesar 2787,13. Artinya setiap penambahan 1 (satu) persen peminjam wanita akan meningkatkan rata-rata jumlah pinjaman sebesar Rp.2.787,126. Koefisien variabel jumlah peminjam wanita memberikan pengaruh positif terhadap rata-rata jumlah pinjaman (AOL), sehingga variabel jumlah peminjam wanita (WANITA) berpengaruh negatif terhadap kedalaman jangkauan. Berdasarkan uji t-statistik variabel jumlah peminjam wanita berpengaruh tidak signifikan terhadap kedalaman jangkauan yang diwakili oleh proksi rata-rata jumlah pinjaman (AOL) dengan asumsi variabel yang lain tetap (ceteris paribus). Meskipun tidak signifikan namun variabel tersebut memberikan pengaruh negatif pada kedalaman jangkauan walaupun pengaruhnya sangat kecil.

Pengaruh positif variabel peminjam wanita terhadap rata-rata pinjaman terjadi karena sebagian besar peminjam wanita yang 
menerima pinjaman kredit di Kecamatan Rambah Kabupaten Rokan Hulu bukan termasuk peminjam miskin yang menjadi objek pemberdayaan. Beberapa peminjam wanita hanya mengatasnamakan pinjaman untuk kebutuhan keluarga, bukan semata-mata karena kebutuhan pribadi. Berdasarkan informasi dari pengelola LKM UED-SP di Kecamatan Rambah, beberapa dari mereka (peminjam wanita) meminjam uang hanya untuk menutupi hutang usaha suami di bank maupun kepada rentenir. Sehingga jika kondisi peminjam wanita seperti itu, maka banyaknya peminjam wanita tidak akan memperdalam jangkauan keuangan mikro.

\section{KESIMPULAN DAN SARAN}

\section{Kesimpulan}

Berdasarkan hasil dan pembahasan yang telah dibahas pada bab sebelumnya, dapat ditarik kesimpulan sebagai berikut:

A. Kinerja Jangkauan Lembaga Keuangan Mikro (LKM) UED-SP di Kecamatan Rambah

1. Berdasarkan data perkembangan jumlah peminjam dan jumlah pinjaman menunjukkan bahwa semakin bertambah umur suatu LKM UED-SP maka semakin meningkatkan keluasan jangkauan ditandai peningkatan jumlah peminjam setiap tahunnya.

2. Secara umum rata-rata jumlah pinjaman cenderung konstan seiring dengan bertambahnya umur lembaga, artinya LKM tersebut tetap konsisten dalam memperhatikan kedalaman jangkauan. Namun terdapat beberapa LKM yang memiliki nilai konstan pada angka yang tinggi bahkan terjadi peningkatan AOL, sehingga dapat mendangkalkan jangkauan LKM tersebut.

3. Nilai ROA yang cenderung mengalami penurunan mengindikasikan bahwa LKM UED-SP tersebut sangat memperhatikan kedalaman jangkauan daripada profitabilitasnya. Namun jika mengacu pada peraturan BI maka secara keseluruhan rata-rata rasio ROA UED-SP di Kecamatan Rambah sudah di atas standar BI yaitu ROA > 1,5 persen. Artinya secara finansial sudah efisien dan tetap dapat menjaga keberlanjutan LKM UED-SP tersebut.

4. Secara keseluruhan jumlah peminjam dari sektor perdagangan meningkat baik setiap tahun. Sehingga jangkauannya akan semakin dalam karena semakin banyak usaha mikro yang dapat dilayani.

5. Secara umum jumlah peminjam dari sektor pertanian juga meningkat baik di beberapa LKM UED-SP di Kecamatan Rambah. Sehingga LKM UED-SP sudah menjangkau masyarakat tani yang dijadikan objek pemberdayaan.

6. Secara keseluruhan walaupun peningkatannya tidak sebanding dengan jumlah peminjam laki-laki namun jumlah peminjam wanita meningkat baik pada tingkat LKM UED-SP. Artinya peminjam wanita sebagai objek pemberdayaan telah terjangkau.

B. Faktor-Faktor yang Mempengaruhi Kedalaman Jangkauan Lembaga Keuangan Mikro (LKM) UED-SP di Kecamatan Rambah

1. Secara bersama-sama menunjukkan bahwa kelima variabel independen (umur lembaga, ROA, proporsi peminjam sektor perdagangan, proporsi peminjam sektor pertanian, dan jumlah peminjam wanita) berpengaruh signifikan terhadap kedalaman jangkauan (depth of outreach).

2. Secara parsial dari lima variabel independen yang digunakan dalam penelitian ini, hanya variabel umur LKM yang berpengaruh secara signifikan terhadap kedalaman jangkauan. Sedangkan variabel, ROA, proporsi peminjam sektor perdagangan, proporsi peminjam sektor pertanian, dan jumlah peminjam wanita hanya memberikan pengaruh yang sangat kecil terhadap kedalaman jangkauan.

3. Tingkat keeratan $\left(\mathrm{R}^{2}\right)$ menunjukkan bahwa sebesar 77,67 persen dari variasi kedalaman jangkauan (depth of outreach) dapat dijelaskan oleh variasi umur lembaga, ROA, proporsi peminjam sektor perdagangan, proporsi peminjam sektor pertanian, dan jumlah peminjam wanita dan sisanya sebesar 
22,33 persen dijelaskan oleh variabel lain yang tidak diteliti dalam penelitian ini.

\section{Saran}

Saran-saran yang dapat diberikan melalui hasil penelitian ini adalah:

1. Pengelola LKM UED-SP yang berada di Kecamatan Rambah Kabupaten Rokan Hulu harus memaksimalkan peran dan tanggung jawab terhadap kinerja jangkauan keuangannya, yaitu tidak hanya fokus pada peningkatan jumlah peminjam (keluasan jangkauan) namun harus memperhatikan kedalaman jangkauan. Artinya tidak melakukan pembatasan bagi masyarakat miskin yang ingin meminjam, sehingga peran LKM UED-SP sebagai fungsi sosial untuk pemberdayaan masyarakat dapat terwujud.

2. Pelaksanaan operasional LKM UED-SP tidak boleh hanya fokus pada profitabilitasnya namun juga harus lebih memperhatikan kedalaman jangkauan sesuai dengan tujuan awal pendirian, yaitu sebagai Program Pemberdayaan Desa (PPD).

3. Sektor perdagangan harus mendapat perhatian lebih dari UED-SP di Kecamatan Rambah, karena sektor ini merupakan jalur masuk bagi pelaku usaha mikro yang dijadikan objek pemberdayaan masyarakat.

4. Sebaiknya lokasi kantor LKM UED-SP lebih dekat dengan masyarakat miskin yang berperan sebagai objek pemberdayaan. Agar masyarakat miskin mudah menjangkau LKM tersebut. Sehingga LKM UED-SP tidak salah sasaran dalam memberikan kredit.

\section{DAFTAR PUSTAKA}

Handayani, P; dan L. Arsyad. 2013. Analisis Faktor-faktor yang Mempengaruhi Kedalaman Jangkauan (Depth of Outreach) Lembaga Keuangan Mikro di Kabupaten Sleman. Jurnal LKM Fakultas Ekonomika dan Bisnis. UGM. Yogyakarta. UGM KINERJA. 17(2); 174-187.

Olivares-Polanco, F. 2005. "Commercializing microfinance and deepening outreach? Empirical evidence from latin America", Journal of Microfinance. 7 (2);47-69.

Ghozali, Imam A. 2015. Analisis Multivarat dan Ekonometrika: Teori, Konsep dan Aplikasi dengan E-views 8. Semarang. Badan Penerbit UNDIP

Laporan Keuangan LKM UED-SP di Kecamatan Rambah 2012-2015

Peraturan Bank Indonesia No.6/9/PBI/2004 tentang Tindak Lanjut Pengawasan dan Penetapan Status Bank

Peraturan Menteri dalam Negeri Republik Indonesia Nomor 140/640/SK tentang Pedoman Alokasi Dana sharing dari Pemerintah Kabupaten/Kota Kepada Desa/Kelurahan tanggal 22 Maret 2005

Quayes, S. 2012. Depth of Outreach and Financial Sustainability of Microfinance Institutions. Applied Economics. Article In Applied Ergonomics. University of Massachusetts Lowell.

Widarjono, A. 2007. Ekonometrika: Teori dan Aplikasi untuk Ekonomi dan Bisnis, Edisi kedua. Penerbit Ekonisia FE UII. Yogyakarta. 


\section{Lampiran 1. Hasil estimasi regresi dengan metode Fixed Effect (FEM)}

Dependent Variable: AOL_(Rp)_Y

Method: Panel Least Squares

Date: 04/06/17 Time: 21:13

Sample: 20122015

Periods included: 4

Cross-sections included: 12

Total panel (balanced) observations: 48

\begin{tabular}{crrrr}
\hline Variable & Coefficient & Std. Error & t-Statistic & Prob. \\
\hline C & 3742939. & 5198210. & 0.720044 & 0.4769 \\
AGE_(Tahun)_X1 & 660653.8 & 272992.4 & 2.420044 & 0.0216 \\
ROA_(\%)_X2 & -55072.47 & 110429.7 & -0.498711 & 0.6215 \\
DAGANG_(\%)_X3 & -15867.94 & 18135.96 & -0.874943 & 0.3883 \\
TANI_(\%)_X4 & 11557.95 & 101199.4 & 0.114210 & 0.9098 \\
WOMAN_(Orang)_X5 & 2787.126 & 13950.33 & 0.199789 & 0.8430 \\
\hline
\end{tabular}

Fixed Effect (Cross)

\begin{tabular}{|c|c|c|c|}
\hline UED-SP & Effect & & \\
\hline Babussalam & -2657388 & & \\
\hline Pematang Berangan & -1715221 & & \\
\hline Tanjung Belit & 467748.0 & & \\
\hline Pasir Baru & -1915530 & & \\
\hline Sialang Jaya & 861148.4 & & \\
\hline Koto Tinggi & -765987.1 & & \\
\hline Rambah Tengah Barat & 2254980 & & \\
\hline Rambah Tengah Hilir & -884194.6 & & \\
\hline Suka Maju Rambah & 1689097. & & \\
\hline Pasir Maju & -111982.8 & & \\
\hline Rambah Tengah Utara & 3083201. & & \\
\hline Pasir Pengaraian & -305871.1 & & \\
\hline \multicolumn{4}{|c|}{ Effects Specification } \\
\hline \multicolumn{4}{|c|}{ Cross-section fixed (dummy variables) } \\
\hline R-squared & 0.776688 & Mean dependent var & 7688817. \\
\hline Adjusted R-squared & 0.661430 & S.D. dependent var & 1885375. \\
\hline S.E. of regression & 1097039. & Akaike info criterion & 30.92525 \\
\hline Sum squared resid & $3.73 E+13$ & Schwarz criterion & 31.58796 \\
\hline Log likelihood & -725.2059 & Hannan-Quinn criter. & 31.17569 \\
\hline F-statistic & 6.738697 & Durbin-Watson stat & 1.660852 \\
\hline Prob(F-statistic) & 0.000003 & & \\
\hline
\end{tabular}

